Utah State University

DigitalCommons@USU

$5-1998$

\title{
An Investigation of Crystalline Intensity of the Wood of Poplar Clones Grown in Jiangsu Province, China
}

Bernard R. Parresol

Fuliang Cao

Follow this and additional works at: https://digitalcommons.usu.edu/aspen_bib

Part of the Agriculture Commons, Ecology and Evolutionary Biology Commons, Forest Sciences

Commons, Genetics and Genomics Commons, and the Plant Sciences Commons

\section{Recommended Citation}

Parresol, Bernard R.; Cao, Fuliang. 1998. An Investigation of Crystalline Intensity of the Wood of Poplar Clones Grown in Jiangsu Province, China. United States Department of Agriculture, Forest Service, Southern Research Station, Research Paper SRS-11. 7p.

This Article is brought to you for free and open access by the Aspen Research at DigitalCommons@USU. It has been accepted for inclusion in Aspen Bibliography by an authorized administrator of DigitalCommons@USU. For more information, please contact

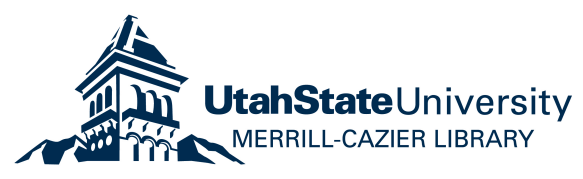


United States

Department of

Agriculture

Forest Service

Forest serma

Southern

Research Station

Research Paper

SRS-11

\section{An Investigation of Crystalline Intensity of the Wood of Poplar Clones Grown in Jiangsu Province, China}

Bernard R. Parresol and Fuliang Cao 
The Authors:

Bernard R. Parresol is a Mathematical Statistician with the Southern Forest Inventory, Monitoring, and Analysis Program (SFIMAP), U.S.

Department of Agriculture, Forest Service, Southern Research Station, Asheville, NC 28802, U.S.A.; and Fuliang Cao is a Professor of Silviculture, College of Forest Resources and Environmental

Sciences, Nanjing Forestry University, Nanjing, Jiangsu 210037, People's Republic of China.

May 1998

Southern Research Station

P.O. Box 2680

Asheville, North Carolina 28802 


\section{An Investigation of Crystalline Intensity of the Wood of Poplar Clones Grown in Jiangsu Province, China

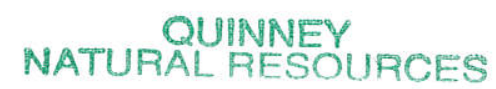

\author{
Bernard R. Parresol and Fuliang Cao
}

\section{Abstract}

Observed trends from limited sampling are reported in this paper. Using $\mathrm{x}$-ray diffractograms, differences in wood fiber crystalline intensity (CrI\%) among four southern-type poplar clones (I-69/55, I-63/51, I-72/58, and I-214) and across four planting spacings ( $4 \mathrm{~m}$ by $4 \mathrm{~m}, 5 \mathrm{~m}$ by $5 \mathrm{~m}, 6$ $\mathrm{m}$ by $6 \mathrm{~m}$, and $7 \mathrm{~m}$ by $7 \mathrm{~m}$ ) were examined. The analyses showed poplar clones I-63/51 and I-214 have the highest CrI\%, followed by I-69/55 and I-72/58. Crystalline intensity of wood gradually increased across annual rings; hence $\mathrm{CrI} \%$ of sapwood was a little higher than that of heartwood. Crystalline intensity of late wood of three of the poplar clones was higher than that of early wood (there was no difference in I-72/58); and as stand density increased, $\mathrm{CrI} \%$ of wood also increased. A fully replicated study is needed to firmly establish these trends.

Keywords: Industrial forests, planting spacing, Populus deltoides, Populus $\times$ eruramericana, $\mathrm{x}$-ray diffractograms.

\section{Introduction}

To establish manmade poplar (Populus spp.) clonal forests for industrial uses, two requirements must be met. First, forests must have high yield; and second, wood fibers must have specific mechanical properties. For example, both fiberboard and plywood require fibers with a certain stiffness and strength. In fact, fiber characteristics are closely related to the fiber's crystalline intensity (CrI\%) (Yingtian 1982).

Cellulose molecules closely linked laterally in aggregates of a few hundred are called microfibrils. In general, within a microfibril, the lateral linkages between cellulose molecules are uniformly ordered. Therefore, the majority of the interior of the microfibril consists of a regular three-dimensional array of cellobiose units - it is crystalline (Wilson and White 1986). Its crystallinity, however, is interrupted along its length by numerous localized regions where the molecules are less regularly packed; the crystalline regions between them being some 50 to 60 nanometers in length. Because wood cell walls contain closely packed and approximately parallel arrays of microfibrils, the similarly parallel crystallites within the microfibrils act, in the aggregate, to confer on the wall as a whole some of the attributes of an overall crystalline

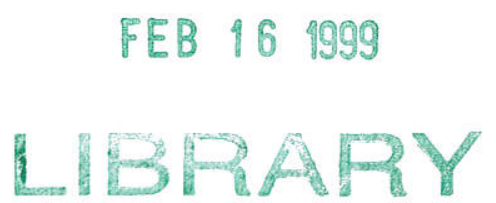

structure. Thus, wood cell walls can be studied by crystallographic methods, such as $\mathrm{x}$-ray diffraction analysis, to determine the crystallinity (crystalline intensity) of the wood fibers (Boyd 1977, Saka 1993, Wilson and White 1986, Yingtian 1982).

The CrI\% of wood affects the properties of the fibers. If CrI\% increases, tensile strength, Young's modulus of elasticity, hardness, density, and stability of size will increase. However, tensile ratio, toughness, pliability, swelling of wood by water, adsorption to dyes, and the rate of chemical reactions will decrease (Zheng 1986). Clonal variety and stand density can influence CrI\%. Crystalline intensity may also vary with early wood (EW)-late wood (LW) formation and across annual rings. $\mathrm{X}$-ray diffraction analysis was used in this trial study to explore the differences in $\mathrm{CrI} \%$ on four common clonal varieties grown in Jiangsu Province. The differences across a range of planting densities were also examined. The resulting information will aid in effectively using the wood of the southern poplar clones.

\section{Materials and Methods}

\section{Site and Sampling}

Sample trees were taken from 14-year-old experimental poplar plantations growing in the Institute of Shuilian Forestry Research Center, Jiangsu Province, China, in the spring of 1991. The plantations were established in the winter of 1978 using a split-plot design with four types of poplar clones as the main plots and four planting densities as the subplots done in four blocks or replicates (Cao and others 1989). The experimental poplars were $P$. deltoides Bartr. cv. 'Harvard' (I-63/51), P. deltoides Bartr. cv. 'Lux' (I-69/55), P. × euramericana (Dode) Guiner cv. 'San Martino' (I-72/58), and P. × euramericana (Dode) Guiner cv. I-214. The planting densities were 204, 278, 400 , and 625 trees per hectare; the corresponding spacings were 7 meters (m) by $7 \mathrm{~m}, 6 \mathrm{~m}$ by $6 \mathrm{~m}, 5 \mathrm{~m}$ by $5 \mathrm{~m}$, and $4 \mathrm{~m}$ by $4 \mathrm{~m}$. 
Time and budgetary constraints restricted this investigation to a one-replicate pilot study. Four randomly picked sample trees - one of each clonal type (I-72/58, I-69/55, I-63/51, and I-214) from stands planted at the 7-m by 7-m spacing-were used to measure differences in $\mathrm{CrI} \%$ among poplar clones. Three additional randomly picked trees from clone I-72/58 - one from each of the remaining planting densities-were used to determine differences in $\mathrm{CrI} \%$ among planting densities.

\section{Diffraction}

Diffractogram specimens came from 10-centimeters $(\mathrm{cm})$ thick disks removed at breast height from each sample tree. Along the upper surface of the disks, EW and LW of growth rings 4 through 13 were distinguished, separated, and cut into small pieces. The small pieces of wood were dried, ground into wood powder, and sifted through a 0.8 millimeter sieve.

$\mathrm{X}$-ray diffraction was used for determining $\mathrm{CrI} \%$ (Boyd 1977, Xie and Sun 1985). A GX-3B-x-ray diffractor was connected to a 2456 diffractometer, and copper $\mathrm{X}$-rays were used as the exciting radiation. During use, the voltage power of the diffractor was 40 kilovolts; the current intensity was 20 milliamperes; and the device speed for angle measurement $(2 \theta)$ was $5^{\circ}$ per minute. The diffraction patterns were obtained by collecting intensities (Geiger counts per second), $\mathrm{I}(2 \theta)$, over the range from $2 \theta=5^{\circ}$ to $2 \theta=40^{\circ}$. Under normal room temperature, the sifted powder was pressed into small slices and placed in the aluminum sample holder for scanning. For each sample, the resulting intensity curve provided two peak values, one at the point where $2 \theta$ equaled $22^{\circ}$, corresponding to the relatively intense reflection of the (002) crystallographic plane of cellulose $\left(\mathrm{I}_{002}\right)$, and the other at the point where $2 \theta$ equaled $18^{\circ}$, corresponding to the amorphous scattering $\left(\mathrm{I}_{\mathrm{am}}\right)$. Based on the Segal method (Xie and Sun 1985), the CrI\% was determined as:

$$
\mathrm{CrI} \%=\frac{\mathrm{I}_{002}-I_{\mathrm{am}}}{I_{002}} \times 100
$$

\section{Analysis}

An analysis of variance (ANOVA) was performed on the CrI\% values from growth rings 4 through 11 (rings 11 through 13 were pooled and labeled 11) of the 4 different clone trees sampled from the stands planted at the $7-\mathrm{m}$ by 7-m spacing. Clone means were separated using the
Ryan-Einot-Grabiel-Welsch multiple F (REGWF) test (SAS Institute Inc. 1989). Polynomial trends in CrI\% over growth rings were tested with orthogonal polynomial contrasts. For each clone, we conducted a paired t-test on EW-LW values. Planting spacing or density effects on CrI\% were analyzed with ANOVA and polynomial contrasts.

\section{Results and Discussion}

\section{Clone, Annual Ring, and EW LW}

Table 1 lists the $64 \mathrm{EW}-\mathrm{LW}$ CrI\% values of the four trees representing each clone at the 7-m by $7-\mathrm{m}$ spacing. The $\mathrm{CrI} \%$ value of a growth ring is the average of its $\mathrm{EW}$ and $\mathrm{LW}$ values. The results of the ANOVA show that $\mathrm{CrI} \%$ differs among clones and that after a decrease in annual ring number $5, \mathrm{CrI} \%$ increases with annual ring number of the tree (table 2, fig. 1). Among the four clones, CrI\% of the I-63/51 clone is the highest $(\bar{x}=47.3), \mathrm{CrI} \%$ of I-214 follows $(\bar{x}=47.0), I-69 / 55$ is third $(\bar{x}=45.5)$, and the I$72 / 58$ clone has the lowest CrI\% $(\bar{x}=44.2)$. Based on the REGWF test, the clones fall into two statistical groups, with clones I-63/51 and I-214 similar (group A) and clones I-69/55 and I-72/58 similar (group B), but groups A and B differ significantly $(\alpha=0.05)$.

From table 2 and figure 1, we can see that there are significant linear and quadratic trends in $\mathrm{Cr} 1 \%$ with annual ring of the trees. While the quadratic trend is significant, the positive linear trend is by far the influential effect.

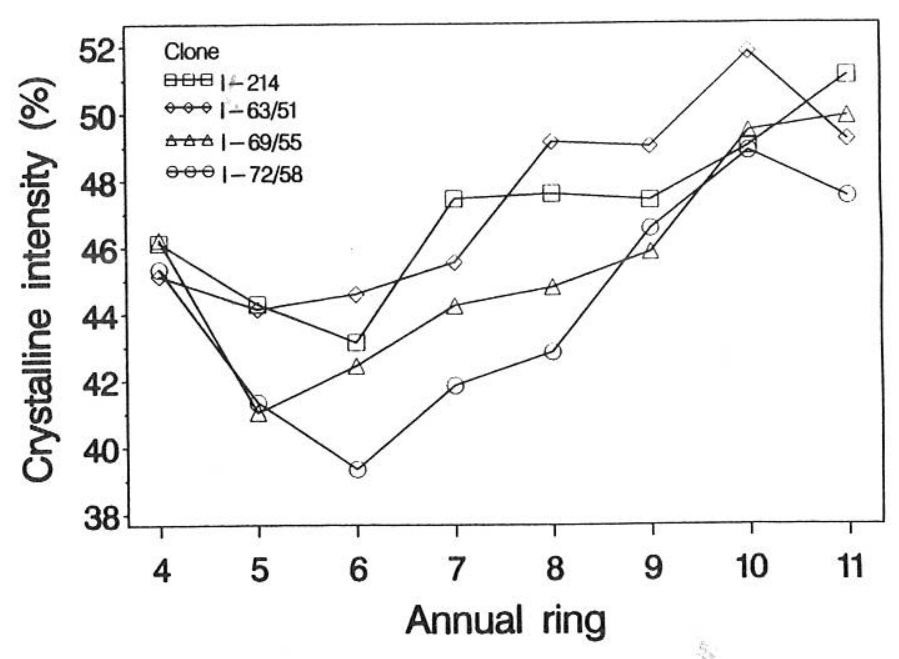

Figure $1-$ Changes in crystalline intensity of four poplar clones with age. 
Table 1-Crystalline intensity of early wood and late wood of four poplar clones

\begin{tabular}{llccccccccc}
\hline & & \multicolumn{8}{c}{ Rings from pith (years) } \\
\cline { 3 - 8 } Clone & Item & 4 & 5 & 6 & 7 & 8 & 9 & 10 & $11-13$ & Average \\
\hline I-72/58 & EW & 43.2 & 42.6 & 40.4 & 40.4 & 41.9 & 45.6 & 48.9 & 49.1 & 44.0 \\
& LW & 47.5 & 40.1 & 38.3 & 43.3 & 43.8 & 47.5 & 48.8 & 45.9 & 44.4 \\
I-69/55 & EW & 44.4 & 40.0 & 42.0 & 46.0 & 43.9 & 44.1 & 48.4 & 48.2 & 44.6 \\
& LW & 48.1 & 42.1 & 42.9 & 42.5 & 45.7 & 47.6 & 50.5 & 51.6 & 46.4 \\
I-214 & EW & 46.8 & 40.9 & 40.1 & 48.9 & 46.4 & 44.6 & 46.2 & 48.8 & 45.3 \\
& LW & 45.5 & 47.7 & 46.2 & 46.0 & 48.8 & 50.2 & 51.8 & 53.4 & 48.7 \\
I-63/51 & EW & 41.8 & 42.8 & 43.2 & 45.3 & 46.1 & 47.1 & 52.0 & 47.3 & 45.7 \\
& LW & 48.5 & 45.5 & 46.0 & 45.8 & 52.2 & 50.9 & 51.6 & 51.1 & 49.0 \\
\hline
\end{tabular}

$\mathrm{EW}=$ early wood; $\mathrm{LW}=$ late wood.

Table 2-Analysis of crystalline intensity of four poplar clones (7-m by 7 -m spacing)

\begin{tabular}{|c|c|c|c|c|c|}
\hline Source & df & SS & MS & $\mathrm{F}$ & $P$ \\
\hline Clone & 3 & 50.08 & 16.69 & 10.58 & 0.0002 \\
\hline Annual ring & 7 & 211.46 & 30.21 & 19.15 & 0.0001 \\
\hline Error & 21 & 33.13 & 1.58 & & \\
\hline \multirow[t]{3}{*}{ Corrected total } & 31 & 294.66 & & & \\
\hline & $\mathrm{r}^{2}$ & C.V. & \multicolumn{2}{|l|}{ Root MSE } & CrI\% Mean \\
\hline & 0.8876 & 2.730 & 1.2560 & & 46.01 \\
\hline Contrast & df & SS & MS & $\mathrm{F}$ & $P$ \\
\hline Ring: linear trend & 1 & 141.07 & 140.07 & 89.43 & 0.0001 \\
\hline Ring: quadratic trend & 1 & 29.84 & 29.84 & 18.92 & 0.0003 \\
\hline
\end{tabular}


That is to say, CrI\% appears to be higher in the outer rings (sapwood) than in the inner rings (heartwood). One possible explanation for the trend is that the gaps between the fibers of the heartwood fill up with a hard noncrystallizing pectin-type substance (Butterfield and Meylan 1980), which makes CrI\% appear to decrease. For the age 5 through 11 data, the rate of increase in $\mathrm{CrI} \%$ (slope of the linear trend) is 1.33 per year.

Among the four clones, I-63/51 and I-214 have the highest CrI\% of both EW and LW, I-69/55 follows, and I$72 / 58$ is the lowest (table 1). For clones I-63/51, I-214, and I-69/55, there are significant differences (based on paired t-tests) between $\mathrm{CrI} \%$ of EW and LW, with CrI\% of LW being higher than that of EW (table 3). But for clone I-72/58, EW and LW values do not differ significantly.

\section{Planting Density}

Table 4 lists the $64 \mathrm{EW}-\mathrm{LW}$ values of the $4 \mathrm{I}-72 / 58$ clone trees, 1 from each stand density. There are significant density and annual ring effects (table 5, figs. 2 and 3 ). As planting spacing increases (density decreases), $\mathrm{CrI} \%$ of wood fibers of I-72/58 decrease in a linear fashion, with the exception of the 7-m by $7-\mathrm{m}$ spacing where $\mathrm{CrI} \%$ rises causing the significant quadratic effect. For the 4-m through 6-m spacing data, the rate of decrease in $\mathrm{CrI} \%$ (slope of the linear trend) is 1.80 per $\mathrm{m}$ change in spacing. The rise at the 7-m spacing could be due to some microsite condition or it could be chance variation.

Crystalline intensity across annual rings, consistent with the earlier analysis, has a strong positive linear trend (table 5, fig. 3). Clone I-72/58, regardless of stand density, shows no significant differences in $\mathrm{CrI} \%$ between EW and LW (table 6). The 'San Martino' cultivar is clearly distinct from the other clones in having uniformity of $\mathrm{CrI} \%$ in the EW and LW of an annual ring.

Table 3-Paired t-tests of early wood vs. late wood crystalline intensity values of four poplar clones; values paired by growth ring

\begin{tabular}{lcccc}
\hline Clone & Mean & $\begin{array}{c}\text { Std. } \\
\text { Error }\end{array}$ & $\mathrm{t}$ & $\begin{array}{c}\text { Prob } \\
>|\mathrm{t}|\end{array}$ \\
\hline & & & & \\
$\mathrm{I}-72 / 58$ & -0.39 & 0.980 & -0.40 & 0.704 \\
$\mathrm{I}-69 / 55$ & -1.75 & 0.825 & -2.12 & 0.072 \\
$\mathrm{I}-214$ & -3.36 & 1.287 & -2.61 & 0.035 \\
$\mathrm{I}-63 / 51$ & -3.25 & 0.866 & -3.75 & 0.007 \\
\hline
\end{tabular}

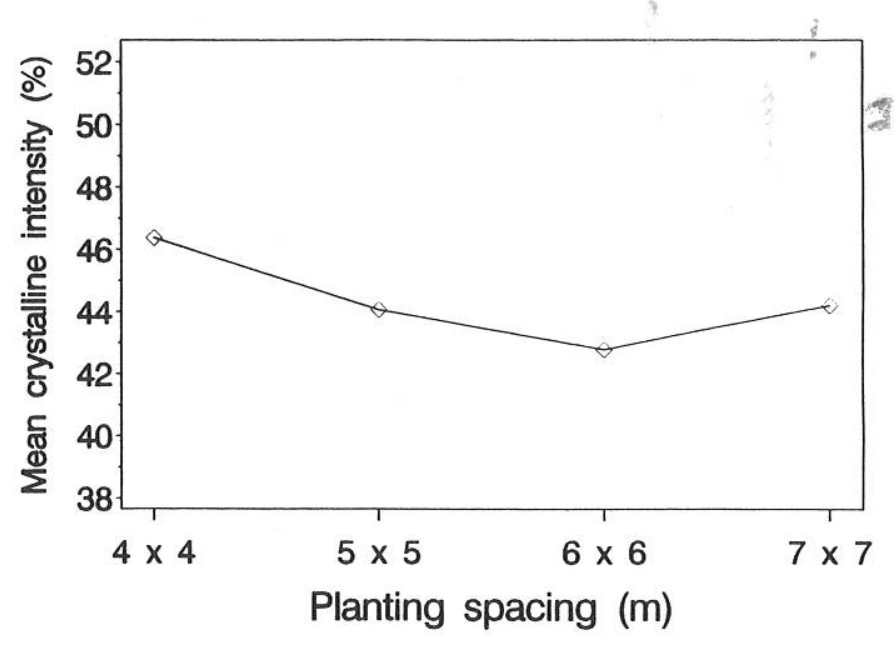

Figure 2-Average crystalline intensity of clone I-72/58 at four planting densities.

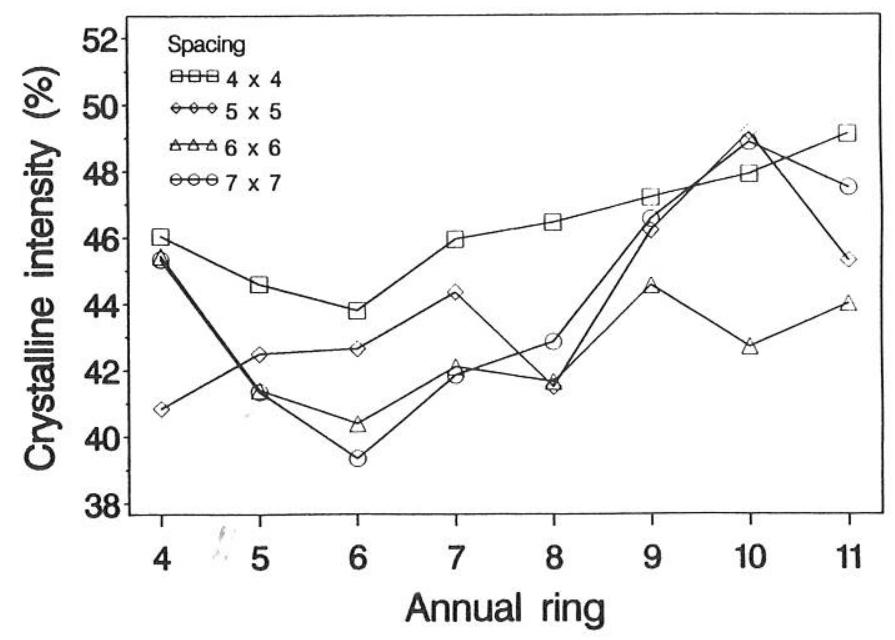

Figure 3-Changes in crystalline intensity of clone I-72/58 with age and planting density. 
Table 4-Crystalline intensity of early wood and late wood of clone I-72/58 grown at four planting spacings

\begin{tabular}{|c|c|c|c|c|c|c|c|c|c|c|}
\hline \multirow[b]{2}{*}{ Spacing } & \multirow[b]{2}{*}{ Item } & \multicolumn{8}{|c|}{ Rings from pith (years) } & \multirow[b]{2}{*}{ Average } \\
\hline & & 4 & 5 & 6 & 7 & 8 & 9 & 10 & $11-13$ & \\
\hline$(m)$ & & i & & & & & & & & \\
\hline $4 \times 4$ & $\begin{array}{l}\text { EW } \\
\text { LW }\end{array}$ & $\begin{array}{l}46.4 \\
45.7\end{array}$ & $\begin{array}{l}42.5 \\
46.7\end{array}$ & $\begin{array}{l}42.9 \\
44.7\end{array}$ & $\begin{array}{l}46.7 \\
45.2\end{array}$ & $\begin{array}{l}45.5 \\
47.4\end{array}$ & $\begin{array}{l}49.7 \\
44.7\end{array}$ & $\begin{array}{l}49.3 \\
46.5\end{array}$ & $\begin{array}{l}52.2 \\
46.0\end{array}$ & $\begin{array}{l}46.9 \\
45.9\end{array}$ \\
\hline $5 \times 5$ & $\begin{array}{l}\text { EW } \\
\text { LW }\end{array}$ & $\begin{array}{l}43.1 \\
38.6\end{array}$ & $\begin{array}{l}43.4 \\
41.6\end{array}$ & $\begin{array}{l}42.8 \\
42.5\end{array}$ & $\begin{array}{l}41.8 \\
46.9\end{array}$ & $\begin{array}{l}37.3 \\
45.7\end{array}$ & $\begin{array}{l}44.3 \\
48.1\end{array}$ & $\begin{array}{l}47.5 \\
50.8\end{array}$ & $\begin{array}{l}47.3 \\
43.3\end{array}$ & $\begin{array}{l}43.4 \\
44.7\end{array}$ \\
\hline $6 \times 6$ & $\begin{array}{l}\text { EW } \\
\text { LW }\end{array}$ & $\begin{array}{l}46.0 \\
44.9\end{array}$ & $\begin{array}{l}42.5 \\
40.3\end{array}$ & $\begin{array}{l}41.2 \\
39.6\end{array}$ & $\begin{array}{l}42.0 \\
42.2\end{array}$ & $\begin{array}{l}40.2 \\
43.1\end{array}$ & $\begin{array}{l}45.1 \\
44.0\end{array}$ & $\begin{array}{l}44.1 \\
41.3\end{array}$ & $\begin{array}{l}44.0 \\
44.0\end{array}$ & $\begin{array}{l}43.1 \\
42.4\end{array}$ \\
\hline $7 \times 7$ & $\begin{array}{l}\text { EW } \\
\text { LW }\end{array}$ & $\begin{array}{l}43.2 \\
47.5\end{array}$ & $\begin{array}{l}42.6 \\
40.1\end{array}$ & $\begin{array}{l}40.4 \\
38.3\end{array}$ & $\begin{array}{l}40.4 \\
43.3\end{array}$ & $\begin{array}{l}41.9 \\
43.8\end{array}$ & $\begin{array}{l}45.6 \\
47.5\end{array}$ & $\begin{array}{l}48.9 \\
48.8\end{array}$ & $\begin{array}{l}49.1 \\
45.9\end{array}$ & $\begin{array}{l}44.0 \\
44.4\end{array}$ \\
\hline
\end{tabular}

$\mathrm{EW}=$ early wood $\mathrm{LW}=$ late wood.

Table 5-Analysis of Crystalline intensity of clone I-72/58 at four planting spacings

\begin{tabular}{|c|c|c|c|c|c|}
\hline Source & df & SS & MS & $\mathrm{F}$ & $P$ \\
\hline Clone & 3 & 53.52 & 17.84 & 6.57 & 0.0026 \\
\hline Annual ring & 7 & 116.26 & 16.61 & 6.11 & 0.0006 \\
\hline Error & 21 & 57.04 & 2.72 & & \\
\hline \multirow[t]{3}{*}{ Corrected total } & 31 & 226.82 & & & \\
\hline & $r^{2}$ & C.V. & Root MSE & \multicolumn{2}{|c|}{ Crl\% Mean } \\
\hline & 0.7485 & 3.716 & 1.6481 & \multicolumn{2}{|c|}{44.36} \\
\hline Contrast & $\mathrm{df}$ & SS & MS & $\mathrm{F}$ & $P$ \\
\hline Spacing: linear trend & 1 & 24.38 & 24.38 & 8.97 & 0.0069 \\
\hline Spacing: quadratic trend & 1 & 28.03 & 28.03 & 10.32 & 0.0042 \\
\hline Ring: linear trend & 1 & 62.08 & 62.08 & 22.85 & 0.0001 \\
\hline Ring: quadratic trend & 1 & 20.74 & 20.74 & 7.63 & 0.0117 \\
\hline
\end{tabular}


Table 6-Paired t-tests of early wood vs. late wood; crystalline intensity values of clone I-72/58 grown at four planting spacings; values paired by growth ring

\begin{tabular}{lrrrr}
\hline Spacing & Mean & $\begin{array}{c}\text { Std. } \\
\text { error }\end{array}$ & $\mathrm{t}$ & \multicolumn{1}{c}{$\begin{array}{c}\text { Prob } \\
>|\mathrm{t}|\end{array}$} \\
\hline$(m)$ & & & & \\
& & & & \\
4 by 4 & 1.04 & 1.267 & 0.82 & 0.440 \\
5 by 5 & -1.25 & 1.631 & -0.77 & 0.469 \\
6 by 6 & 0.71 & 0.627 & 1.14 & 0.294 \\
7 by 7 & -0.39 & 0.980 & -0.40 & 0.704 \\
\hline
\end{tabular}

\section{Implications}

From this pilot study, the following suppositions are offered: (1) based on the CrI\% of clones, I-63/51 and I214 are the stiffest and strongest, followed by I-69/55 and I-72/58; (2) because CrI\% of the four poplar clones increases at a linear rate of 1.33 per year, $\mathrm{CrI} \%$ of sapwood is higher than that of heartwood; (3) CrI\% of LW is higher than that of EW, except in clone I-72/58; and (4) based on the linear increase (slope $=1.80$ ) of $\mathrm{CrI} \%$ in poplar I-72/58 as planting spacing decreases, poplars growing in denser stands should have increased fiber strength. While no firm conclusions can be drawn, constant monitoring of growth in the Shuilian plantations has shown that diameter and height do not differ significantly among individual trees in each clonal stand (Cao and others 1989), therefore, reasonably small withinclone $\mathrm{CrI} \%$ variation is expected.
As pulp-making raw material, poplar wood should possess a high cellulose content and a low lignin content (Doupin 1986). Only the clones with high $\mathrm{CrI} \%$ can meet these conditions. Because poplar I-63/51 has the highest $\mathrm{CrI} \%$ when planted at the 7-m by 7-m spacing and because $\mathrm{CrI} \%$ apparently increases as spacing decreases, this poplar clone should have the highest $\mathrm{CrI} \%$ at $4-\mathrm{m}$ by $4-\mathrm{m}$ planting spacing, making it the clone with the highest quality in pulp and paper-making characteristics. With a stand rotation period of 5 to 7 years, the diameter at breast height of individual trees can reach more than 20 centimeters (Cao and others 1989), which meets the requirements of the paper-making industry.

In theory, the quality of fiberboard is a direct function of fiber strength. The strength of fibrous cells are related to microfibril angle, $\mathrm{Cr} \%$, and the degree of polymerization (Northeast Forestry University 1981, Page and others 1977, Sun and Xie 1981). Our suppositions suggest that clone I-63/51 or I-214 at planting spacings of 4-m by 4-m or less, grown for extremely short rotation periods of 4 to 5 years, will make strong fiberboard. To produce pliable fiberboard, fast-growing clones I-72/58 and I-69/55 can be planted at spacings of $6-\mathrm{m}$ by $6-\mathrm{m}$ and $7-\mathrm{m}$ by $7-\mathrm{m}$ and grown for short rotation periods of 8 to 10 years.

\section{Acknowledgment}

We thank professors Lu Shizing, Huang Minren, Yuan Xigen, and Li Dagang, Nanjing Forestry University, for their financial support and technical direction. We also appreciate the technical assistance of Mr. Gong Shigan and Ms. Xu Lin. 


\section{Literature Cited}

Boyd, J.D. 1977. Interpretation of x-ray diffractograms of wood for assessments of microfibril angles in fibre cell walls. Wood Science and Technology. 11(2): 93-114.

Butterfield, B.G.; Meylan, B.A. 1980. Three-dimensional structure of wood: an ultrastructural approach, 2d ed. New York: Chapman and Hall. 103 p.

Cao, F.; Lu, S.; Xu, X.; Huang, M. 1989. A study on growth characteristics of southern type clones. In: Symposium on techniques for fast-growth and high yield in southern type poplars. [Date of meeting unknown]: [Place of meeting unknown] Beijing, China: Academic Book and Periodical Press: 81-93. In Chinese.

Doupin, Z. 1986. Introduction to wood application. Shanghai, China: Shanghai Science and Technology Press. In Chinese.

Northeast Forestry University (NFU). 1981. Science of fibreboardmaking. Beijing, China: China Forestry Press. In Chinese.

Page, D.H.; El-Hosseiny, F.; Winkler, K.; Lancaster, A.P. 1977. Elastic modulus of single wood pulp fibers. TAPPI. 60(4): 114-117.
Saka, S. 1993. Structure and chemical composition of wood as a natural composite material. In: Shiraishi, N.; Kajita, H.; Norimoto, M., eds. Recent research on wood and wood-based materials- (current Japanese materials research; Vol. 11). Cambridge, England: Elsevier Science Publishers Ltd. and The Society of Materials Science, Japan, through University Press: 1-20.

SAS Institute Inc. 1989. SAS/STAT user's guide, version 6, 4th ed., vol. 2. Cary, NC: SAS Institute Inc.

Sun, C.; Xie, G. 1981. Study on relative crystalline intensity of fibres of P. Massonina. Forestry Science 20(3): 290-299. Beijing, China; In Chinese.

Wilson, K.; White, D.J.B. 1986. The anatomy of wood: its diversity and variability. London, England: Stobart \& Son Ltd.

Xie, G.; Sun, C. 1985. Measurement of microstructure of fibres by means of x-ray diffraction. Journal of Nanjing Forestry College. 3: 61-68. In Chinese.

Yingtian, Y. 1982. Chemistry of fibres. Beijing, China: Spinning and Weaving Industry Press. In Chinese.

Zheng, Y.Z. 1986. Chemistry of wood. Beijing, China: China Forestry Press. In Chinese. 
Parresol, Bernard R.; Cao, Fuliang. 1998. An investigation of crystalline intensity of the wood of poplar clones grown in Jiangsu Province, China. Res. Pap. SRS-11. Asheville, NC: U.S. Department of Agriculture, Forest Service, Southern Research Station. 7 p.

Observed trends from limited sampling are reported in this paper. Using x-ray diffractograms, differences in wood fiber crystalline intensity $(\mathrm{CrI} \%)$ among four southerntype poplar clones (I-69/55, I-63/51, I-72/58, and I-214) and across four planting spacings (4 $\mathrm{m}$ by $4 \mathrm{~m}, 5 \mathrm{~m}$ by $5 \mathrm{~m}, 6 \mathrm{~m}$ by $6 \mathrm{~m}$, and $7 \mathrm{~m}$ by $7 \mathrm{~m}$ ) were examined. The analyses showed poplar clones I-63/51 and I-214 have the highest CrI\%, followed by I-69/55 and I-72/58. Crystalline intensity of wood gradually increased across annual rings; hence CrI\% of sapwood was a little higher than that of heartwood. Crystalline intensity of late wood of three of the poplar clones was larger than that of early wood (there was no difference in I$72 / 58)$; and as stand density increased, CrI\% of wood also increased. A fully replicated study is needed to firmly establish these trends.

Keywords: Industrial forests, planting spacing, Populus deltoides, Populus $\times$ eruramericana, $\mathrm{x}$-ray diffractograms. 
II The Forest Service, United States Department of Agriculture (USDA), is dedicated to the principle of multiple use management of the Nation's forest resources for sustained yields of wood, water, forage, wildlife, and recreation. Through forestry research, cooperation with the States and private forest owners, and management of the National Forests and National Grasslands, it strives-as directed by Congress- to provide increasingly greater service to a growing Nation.

The USDA prohibits discrimination in all its programs and activities on the basis of race, color, national origin, gender, religion, age, disability, political beliefs, sexual orientation, and marital or family status. (Not all prohibited bases apply to all programs.) Persons with disabilities who require alternative means for communication of program information (Braille, large print, audiotape, etc.) should contact USDA's TARGET Center at (202) 720-2600 (Voice and TDD).

To file a complaint of discrimination, write USDA, Director, Office of Civil Rights, Room 326-W, Whitted Building, $14^{\text {th }}$ and Independence Avenue, SW, Washington, DC 20250-9410, or call (202) 720-5964 (voice or TDD). USDA is an equal opportunity provider and employer.

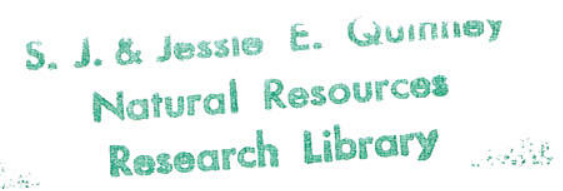

